http://jmscr.igmpublication.org/home/ ISSN (e)-2347-176x ISSN (p) 2455-0450

crossref DOI: https://dx.doi.org/10.18535/jmscr/v8i3.64

\title{
Cytopathological Study of Palpable Superficial Lymph Nodes: A One Year Retrospective Study in Tertiary care Hospital at Muzaffarpur, Bihar
}

\author{
Authors \\ Dr Pankaj K Patel ${ }^{1 *}$, Dr Abhilasha ${ }^{2}$, Dr Vivek Kumar Pandey ${ }^{3}$, Dr Manoj Kumar \\ ${ }^{1}$ Associate Professor, Department of Pathology, S. K. Medical College, Muzaffarpur \\ ${ }^{2}$ Tutor/Senior Resident, Department of Pathology, S. K. Medical College, Muzaffarpur \\ ${ }^{3}$ Tutor/Senior Resident, Department of Pathology, S. K. Medical College, Muzaffarpur \\ ${ }^{4}$ Professor and H.O.D., Department of Pathology, S. K. Medical College, Muzaffarpur \\ *Corresponding Author \\ Dr Pankaj K Patel
}

Associate professor, Department of Pathology, S. K. Medical College, Muzaffarpur, India

\section{Abstract}

Objective: The aim of present study was to evaluate the role of FNAC as a diagnostic tool in a cases of lymphadenopathy.

Material and Methods: A total 124 patients with palpable lymph nodes of different age groups of both sexes were referred for FNAC in the department of pathology, Sri Krishna Medical College, Muzaffarpur during the period of November 2018 to October 2019. Among 124 cases, 6 cases were excluded from the study due to inadequate materials, hence we analysed 118 cases only.

Result: Male to female ratio was 1.14:1. Tubercular lymphadenitis was the commonest lesions in 45 (38.13\%) cases followed by reactive hyperplasia in 40 (33.13\%) cases. Among the neoplastic lesion lymphoma (Hodgkin's and Non hodgkin's) was the commonest pathological findings in 10 (8.47\%) cases followed by metastasis in $5(4.23 \%)$ cases.

Conclusion: Fine needle aspiration cytology is a primary diagnostic tool in the evaluation of lymph node lesions due to its low cost, simplicity and minimal invasiveness.

Keyword: Lymph node, FNAC, tubercular lymphadenitis.

\section{Introduction}

Lymphadenopathy is one of the commonest clinical presentations of patients of all age groups attending the outdoor department. The aetiology varies from a benign non-specific inflammation to lympho-proliferative disorder and metastatic malignancy. Fine needle aspiration cytology (FNAC) is simple, minimally invasive and rapid diagnostic technique in evaluating lymphadenopathy. This technique gives speedy result $^{[1]}$. Several studies ${ }^{[2-5]}$ in the past have documented the diagnostic efficacy of FNAC to lymphadenopathy. It can be used as safe alternative to excision biopsy ${ }^{[6]}$. The present study is undertaken to evaluate the usefulness of FNAC as a diagnostic tool in a cases of lymphadenopathy and assessments to distinguish between metastases, infectious diseases, reactive hyperplasia and lymphomas. 


\section{Materials and Methods}

Present study was a retrospective review of FNAC of lymph node between November 2018 to October 2019 in the department of pathology, Sri Krishna Medical College, Muzaffarpur. Stains used were Grunwald-Giemsa and papanicolaou. Ziehl-Neelson stain was done for all the cases where necrotic material was aspirated or clinically suspected tuberculosis and HIV. Clinical details with regard to age, sex, site, size, duration and other investigations performed were recorded. Among 124 cases those who underwent FNAC of lymph nodes, in 118 cases aspirate was satisfactory and 6 cases were excluded from the study due to inadequate material even after repeated aspiration or the cytological opinion was equivocal.

The cases were divided into six groups, eg: reactive lymphoid hyperplasia, acute non specific lymphadenitis, tuberculous lymphadenitis, metastatic malignancy, lymphoma and a miscellaneous group showing features that did not confirm to any of the earlier mentioned groups ${ }^{[7]}$.

\section{Results}

Out of 124 cases, 6 cases were excluded from the study due to inadequate material or the cytological opinion was equivocal. Fine needle aspiration of 118 cases were finally considered in the study. FNAC of lymph nodes was done at different age groups ranging from 5 years to 70 years. Among 118 patients referred for FNAC, majority of the patients were in the age group of 11-20 years with $33(27.96 \%)$, followed by those in the $21-30$ years with $29(24.57 \%)$ and the least in the $>60$ years with 5 (4.23\%). [Table - I].

Table - I Distribution of cases according to age group ( $\mathrm{n}=118)$.

\begin{tabular}{|l|c|c|}
\hline Age group (in year) & No. of cases & $\%$ of total \\
\hline$<10$ & 23 & $19.49 \%$ \\
\hline $11-20$ & 33 & $27.96 \%$ \\
\hline $21-30$ & 29 & $24.57 \%$ \\
\hline $31-40$ & 9 & $7.62 \%$ \\
\hline $41-50$ & 11 & $9.32 \%$ \\
\hline $51-60$ & 8 & $6.77 \%$ \\
\hline$>60$ & 5 & $4.23 \%$ \\
\hline
\end{tabular}

Table - II Gender wise distribution of cases $(\mathrm{n}=118)$.

\begin{tabular}{|l|c|c|}
\hline Gender & No. of cases & \% of total \\
\hline Males & 63 & $53.38 \%$ \\
\hline Females & 55 & $46.61 \%$ \\
\hline
\end{tabular}

Table - III Religion wise distribution of cases $(\mathrm{n}=118)$.

\begin{tabular}{|l|c|c|}
\hline Religion & No. of cases & \% of total \\
\hline Hindu & 92 & $77.96 \%$ \\
\hline Muslim & 24 & $20.33 \%$ \\
\hline Christian & 2 & $1.69 \%$ \\
\hline
\end{tabular}

Table - IV Distribution of cases according to FNAC findings $(\mathrm{n}=118)$.

\begin{tabular}{|l|l|l|}
\hline FNAC findings & No. of cases & $\%$ of total \\
\hline Tubercular lymphadenitis & 45 & $38.13 \%$ \\
\hline Reactive hyperplasia & 40 & $33.89 \%$ \\
\hline $\begin{array}{l}\text { Acute non specific } \\
\text { lymphadenitis }\end{array}$ & 16 & $13.55 \%$ \\
\hline $\begin{array}{l}\text { Lymphoma (Hodgkins } \\
\text { and Non hodgkins) }\end{array}$ & 10 & $8.47 \%$ \\
\hline Metastatic tumour & 5 & $4.23 \%$ \\
\hline Miscellaneous & 2 & $1.69 \%$ \\
\hline
\end{tabular}

Out of 118 cases, 63 (53.38\%) were males and 55 $(46.61 \%)$ were females and the male to female ratio was $1.14: 1$ (Table - II).

As shown in table - III in the present study Hindus were 92 (77.96\%), followed by Muslims $24(20.33 \%)$ and Christians 2 (1.69\%).

As shown in table - IV, out of total 118 patients subjected to cytological evaluation by fine needle aspiration cytology, tubercular lymphadenitis was the commonest lesions 45 (38.13\%) encountered among benign lesions followed by reactive hyperplasia in $40(33.89 \%)$ cases. Among the neoplastic lesion, lymphoma (Hodgkins and Non hodgkins) was the commonest pathological findings detected on cytology in $10(8.47 \%)$ cases followed by metastasis in $5(4.23 \%)$ cases.

As shown in table- $\mathrm{V}$, generalised lymphadenopathy was present in $8(6.77 \%)$ patients and cervical lymph node was the commonest site involved in $64(54.23 \%)$ patients. 
Table - V Showing anatomical distributions of enlarged lymph nodes $(n=118)$.

\begin{tabular}{|l|c|c|c|}
\hline SI & Anatomic site & $\begin{array}{c}\text { No. of } \\
\text { cases }\end{array}$ & $\%$ of total \\
\hline A & Generalised & 8 & $6.77 \%$ \\
\hline B & Localised & 110 & $93.22 \%$ \\
\hline & Cervical & 64 & $54.23 \%$ \\
\hline & Axillary & 5 & $4.23 \%$ \\
\hline & Inguinal & 4 & $3.38 \%$ \\
\hline & Supraclavicular & 19 & $16.10 \%$ \\
\hline & Submandibular & 14 & $11.86 \%$ \\
\hline & Submental & 2 & $1.69 \%$ \\
\hline & Others & 2 & $1.69 \%$ \\
\hline
\end{tabular}

\section{Discussion}

Lymphadenopathy presents an opportunity for a quick and efficient way to reach an early diagnosis through fine needle aspiration cytology (FNAC) of the involved lymph node ${ }^{[8]}$.

Amongst 124 cases, 118 cases were satisfactory and 6 cases were unsatisfactory. So, the ratio of satisfactory to unsatisfactory smears was 19.66: 1. Whereas in the study of T F Lioe et al (1999) ${ }^{[9]}$ it was $5.27: 1$, Ruchi et al $(2006)^{[10]}$ it was $64.6: 1$ and $10.94: 1$ in Sumit et al $(2001)^{[11]}$.

In our study majority of the patients were in the age group of 11-20 years with 33 (27.96\%), whereas in the study of Pandit A A et al (1987) ${ }^{[12]}$ most of the patients $146(51.05 \%)$ were in the age group of 21-40 years. Age group s >60 years were least affected with $5(4.23 \%)$ cases which is similar to the observation of Gupta et $\mathrm{al}^{[4]}$ showing $4.31 \%$.

Out of 118 patients, 63 patients $(53.38 \%)$ were males and 55 patients $(46.61 \%)$ were females with male to female ratio of 1.14: 1. Similar observations are seen in the study of Hirachand et al (2009) ${ }^{[13]}$ with male to female ratio of $1: 0.9$.

In the present study, the cervical region being the commonest site of enlarged lymph nodes in 64 $(54.23 \%)$ patients followed by supraclavicular in $19(16.10 \%)$ and submandibular in 14 (11.86\%). Similar results were seen in the study of Hirachand et al (2009) ${ }^{[13]}$ where cervical lymph nodes were enlarged in $50.76 \%$ of cases.

In this study tuberculous lymphadenitis (Fig.-I) emerged as the commonest cause of lymphadenitis with 45 cases $(38.13 \%)$ followed by reactive hyperplasia (Fig.-II) with 40 cases $(33.89 \%)$. This may be explained by the fact that in a developing country like ours, all cases of granulomatous lymphadenopathy were considered to be due to tuberculosis ${ }^{[5]}$. Epithelioid cells granuloma with caseous necrosis is the consistent cytological findings of tubercular lymphadenitis. However, in immunocompromised patients lymph node may sometimes show necrotic debri only. Acid fast bacilli should, of course, be looked for both in direc $t$ smears and in culture from the aspirate $^{[14,15]}$. Ruchi et al (2006) ${ }^{[10]}$ in their study had $52.3 \%$ of tubercular and $37.2 \%$ of reactive lymphadenitis.

Among neoplastic lesions, in our study the most common cytological diagnosis was lymphoma in $8.47 \%$ followed by metastatic lesions (Fig. - III) in $4.23 \%$. It differs from studies of Hirachand et al (2009) ${ }^{[13]}$ with

$12.3 \%$ metastatic lesions and 6\% lymphomas.

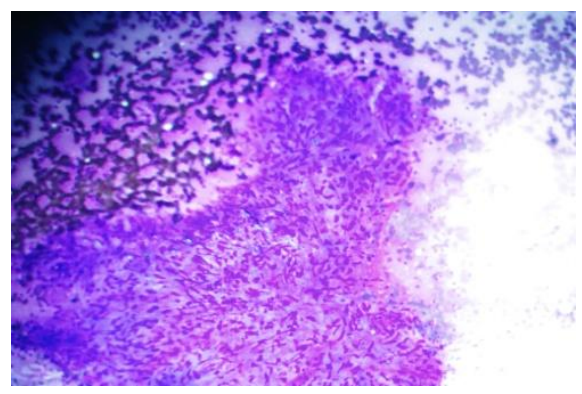

Fig. I: Tubercular lymphadenitis showing aggregates of epithelioid cells, FNAC, Giemsa stain, X 400

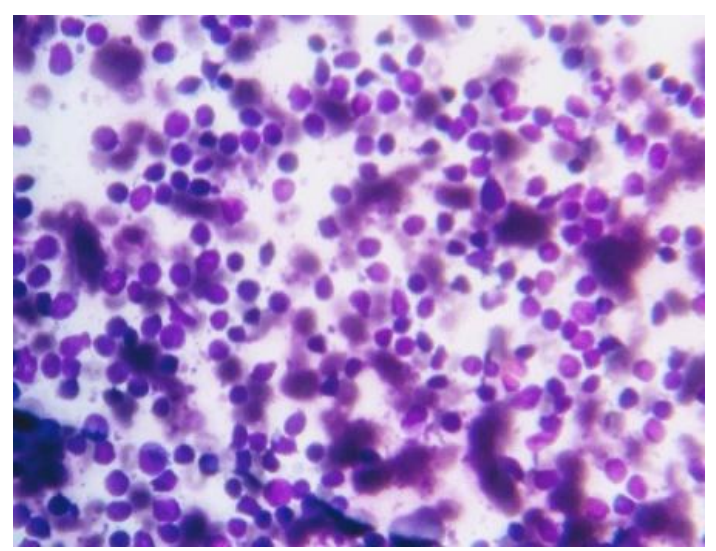

Fig. II: Reactive hyperplasia of lymph node showing predominance of small mature lymphocytes, FNAC, Giemsa stain, X 400 


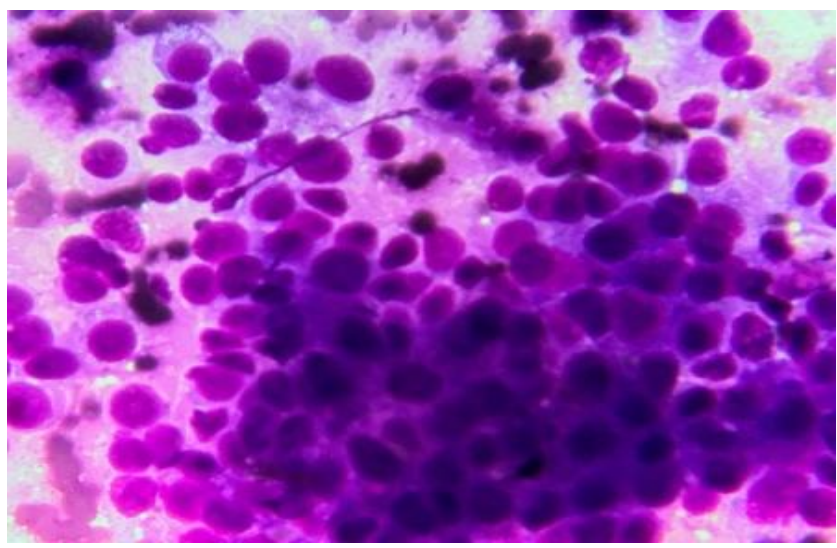

Fig. III: Metastatic adenocarcinoma, FNAC, Giemsa stain, X 400

\section{Conclusion}

Fine needle aspiration cytology is a primary diagnostic tool in the evaluation of lymph node lesions due to its low cost, simplicity, minimal invasiveness and readily acceptable by patient. FNAC alone can help in establishing the diagnosis in large number of cases and save the patient from unnecessary surgical procedure like biopsy.

\section{References}

1. Orell SR, Sterrett GF. Fine Needle Aspiration Cytology. $5^{\text {th }}$ Ed. Edinburgh : Churchill Livingstone ; 2012

2. Steel BL, Schwartz MR, Ramzy I - Fine needle aspiration biopsy in the diagnosis of lymphadenopathy in 1,103 patients: role, limitations, and analysis of diagnostic pitfalls. Acta Cytol 1995; 39: 76-81

3. Nasuti JF, Yu G, Boudousquie A, Gupta P - Diagnostic value of lymph node fine needle aspiration cytology: an institutional experience of 387 cases observed over a 5year period. Cytopathology 2000; 11: 1831

4. Gupta RK, Naran S, Lallu S, Fauck R The diagnostic value of fine needle aspiration cytology (FNAC) in the assessment of palpable supraclavicular lymph nodes: a study of 218 cases. Cytopathology 2003; 14: 201-7

5. Das DK - Lymph nodes. In: Bibbo $\mathbf{M}$, editor. Comprehensive Cytopathology. $2^{\text {nd }}$ ed. Philadelphia: WB Saunders, 1997: 703-29.

6. Ajmall F, Imran A. Comparison of FNAC vs excision biopsy for suspected tuberculous cervical lymphadenopathy. Ann King Edward Med Coll 2013; 9:216-8

7. Nasuti JF, Mehrotra R, Gupta PK. Diagnostic value of fine needle aspiration in Supraclavicular lymphadenopathy : a study of 106 patients and review of literature. Diagn Cytopathol. 2001; 25:351-5.

8. Garbyal RS, Basu D, Roy S, Kumar P. Cryptococcal lymphadenitis: Report of a case with fine needle aspiration cytology. Acta Cytol 2005; 49: 58-60

9. T. F. Lioe, H. Elliott, D.C. Allen and R. A.J. Spence. The role of fine needle aspiration cytology in the investigation of superficial lymphadenopathy : uses and limitations of the technique. Cytopathology $1999 ; 10: 291-297$.

10. Ruchi Khajuria, K.C. Goswami, K. Singh, V.K. Dubey. Pattern of lymphadenopathy on Fine Needle Aspiration Cytology in Jammu ; JK science 2006; 8(3) : 23-28

11. Sumit Mitra, Sucandra Ray, Pradip K Mitra. Fine needle aspiration cytology of supraclavicular lymph nodes : Our experience over a three-year period. Journal of Cytology 2011 ; 28(3) : 52-57

12. Pandit A A, Candes FP, Khub Chandini SR. Fine needle aspiration cytology of lymph nodes. Journal of postgraduate medicine : 1987 ; 33(3) : 134-136

13. Hirachand S, Lakhey M, Akhter J, Thapa B. Evaluation of fine needle aspiration cytology of lymph nodes in Kathmandu Medical College, Teaching hospital. Kathmandu University Medical Journal 2009 ; 7(26) : 139 - 142

14. Bailey TM, Akhtar M, Ali MA. Fine needle aspiration biopsy in the diagnosis of tuberculosis. Acta Cytol. 1985;29:732736. 
15. Radhika S, Gupta SK, Chakrabarti A, et al. Role of culture for mycobacteria in fine needle aspiration diagnosis of tuberculous lymphadenopathy. Diagn Cytopathol. 1989: 5 : 260-262. 